\section{Nitrogen Requirements and N Status Determination of Lettuce}

\author{
Thomas G. Bottoms \\ Department of Plant Sciences, University of California, 1 Shields Avenue, \\ Davis, CA 95616
}

\author{
Richard F. Smith and Michael D. Cahn \\ University of California Cooperative Extension, Salinas, CA
}

Timothy K. Hartz ${ }^{1}$

Department of Plant Sciences, University of California, 1 Shields Avenue, Davis, CA 95616

\section{Additional index words. fertilizer efficiency, soil and tissue testing, Lactuca sativa}

\begin{abstract}
As concern over $\mathrm{NO}_{3}-\mathrm{N}$ pollution of groundwater increases, California lettuce growers are under pressure to improve nitrogen $(\mathrm{N})$ fertilizer efficiency. Crop growth, $\mathbf{N}$ uptake, and the value of soil and plant $\mathbf{N}$ diagnostic measures were evaluated in 24 iceberg and romaine lettuce (Lactuca sativa L. var. capitata L., and longifolia Lam., respectively) field trials from 2007 to 2010 . The reliability of presidedressing soil nitrate testing (PSNT) to identify fields in which $\mathrm{N}$ application could be reduced or eliminated was evaluated in 16 non-replicated strip trials and five replicated trials on commercial farms. All commercial field sites had greater than $20 \mathrm{mg} \cdot \mathrm{kg}^{-1}$ residual soil $\mathrm{NO}_{3}-\mathrm{N}$ at the time of the first in-season $\mathrm{N}$ application. In the strip trials, plots in which the cooperating growers' initial sidedress $\mathbf{N}$ application was eliminated or reduced were compared with the growers' standard $\mathbf{N}$ fertilization program. In the replicated trials, the growers' $N$ regime was compared with treatments in which one or more $\mathbf{N}$ fertigation through drip irrigation was eliminated. Additionally, seasonal N rates from 11 to $336 \mathrm{~kg} \cdot \mathrm{ha}^{-1}$ were compared in three replicated drip-irrigated research farm trials. Seasonal $\mathbf{N}$ application in the strip trials was reduced by an average of $77 \mathrm{~kg} \cdot \mathrm{ha}^{-1}\left(73 \mathrm{~kg} \cdot \mathrm{ha}^{-1} \mathrm{vs} .150 \mathrm{~kg} \cdot \mathrm{ha}^{-1}\right.$ for the grower $\mathrm{N}$ regime) with no reduction in fresh biomass produced and only a slight reduction in crop $\mathrm{N}$ uptake $\left(151 \mathrm{~kg} \cdot \mathrm{ha}^{-1} \mathrm{vs} .156 \mathrm{~kg} \cdot \mathrm{ha}^{-1}\right.$ for the grower $\mathrm{N}$ regime). Similarly, an average seasonal $N$ rate reduction of $88 \mathrm{~kg} \cdot \mathrm{ha}^{-1}\left(96 \mathrm{~kg} \cdot \mathrm{ha}^{-1} \mathrm{vs} .184\right.$ $\mathrm{kg} \cdot \mathrm{ha}^{-1}$ ) was achieved in the replicated commercial trials with no biomass reduction. Seasonal $\mathrm{N}$ rates between 111 and $192 \mathrm{~kg} \cdot \mathrm{ha}^{-1}$ maximized fresh biomass in the research farm trials, which were conducted in fields with lower residual soil $\mathrm{NO}_{3}-\mathrm{N}$ than the commercial trials. Across fields, lettuce $N$ uptake was slow in the first 4 weeks after planting, averaging less than $0.5 \mathrm{~kg} \cdot \mathrm{ha}^{-1} \cdot \mathrm{d}^{-1}$. N uptake then increased linearly until harvest $\left(\approx 9\right.$ weeks after planting), averaging $\approx 4 \mathrm{~kg} \cdot \mathrm{ha}^{-1} \cdot \mathrm{d}^{-1}$ over that period. Whole plant critical $N$ concentration $\left(N_{c}\right.$, the minimum whole plant $N$ concentration required to maximize growth) was estimated by the equation $\mathrm{N}_{\mathrm{c}}\left(\mathrm{g} \cdot \mathrm{kg}^{-1}\right)=42-2.8 \mathrm{dry}$ mass $(\mathrm{DM}$, ${\mathrm{Mg} \cdot \mathrm{ha}^{-1}}^{-1}$; on that basis, critical $\mathrm{N}$ uptake (crop $\mathrm{N}$ uptake required to maintain whole plant $\mathrm{N}$ above $\mathrm{N}_{\mathrm{c}}$ ) in the commercial fields averaged $116 \mathrm{~kg} \cdot \mathrm{ha}^{-1}$ compared with the mean uptake of $145 \mathrm{~kg} \cdot \mathrm{ha}^{-1}$ with the grower $\mathrm{N}$ regime. Soil $\mathrm{NO}_{3}-\mathrm{N}$ greater than $20 \mathrm{mg} \cdot \mathrm{kg}^{-1}$ was a reliable indicator that $\mathrm{N}$ application could be reduced or delayed. Neither leaf $\mathrm{N}$ nor midrib $\mathrm{NO}_{3}-\mathrm{N}$ was correlated with concurrently measured soil $\mathrm{NO}_{3}-\mathrm{N}$ and therefore of limited value in directing in-season $\mathrm{N}$ fertilization.
\end{abstract}

The coastal valleys of central California produce nearly 60,000 ha of lettuce annually, more than half of the nation's supply. In this region, lettuce is typically produced in rotation with other leafy vegetables. Production systems are characterized by two to three crops per year with frequent irrigation and heavy $\mathrm{N}$ fertilization. Water quality monitoring in the agricultural watersheds in this region has shown that both surface water and groundwater often exceed the federal drinking water standard of

Received for publication 8 Aug. 2012. Accepted for publication 18 Oct. 2012.

${ }^{1}$ To whom reprint requests should be addressed; e-mail tkhartz@ucdavis.edu.
Studies on lettuce response to $\mathrm{N}$ fertilization have reported widely varying results. Seasonal $\mathrm{N}$ rates required to maximize crop yield have ranged from 100 to $150 \mathrm{~kg} \cdot \mathrm{ha}^{-1}$ (Gardner and Pew, 1972, 1974, 1979; Tei et al., 2003) to greater than $220 \mathrm{~kg} \cdot \mathrm{ha}^{-1}$ (Hoque et al., 2010; Welch et al., 1979). Much of this variability may be attributed to field-specific factors affecting crop yield potential and $\mathrm{N}$ fertilizer efficiency; these factors include plant population, precipitation, irrigation efficiency, residual soil $\mathrm{NO}_{3}-$ $\mathrm{N}$, and soil $\mathrm{N}$ mineralization potential. Given the high crop value and strict market standards for lettuce, growers commonly use standard fertilization programs with little field-specific modification; they are reluctant to modify current $\mathrm{N}$ fertilizer practices without a sound understanding of the interaction of these factors and reliable diagnostic techniques to guide field-specific $\mathrm{N}$ fertilization.

Adding to the uncertainty regarding efficient $\mathrm{N}$ management of lettuce, California growers continue to modify production practices to increase yield. Average lettuce yield rose $\approx 11 \%$ between 2000 and 2010 (Monterey County Agricultural Commissioner, 2000, 2010); factors potentially responsible included modified planting configurations that increased plant population and widespread adoption of drip irrigation. We undertook this study to develop detailed information on lettuce $\mathrm{N}$ requirements under current production practices used in California's central coast region and to critically evaluate the value of soil and plant diagnostic techniques to guide in-season $\mathrm{N}$ fertilizer management.

\section{Materials and Methods}

Lettuce $\mathrm{N}$ uptake and response to $\mathrm{N}$ fertilization were evaluated in 24 field trials in the Salinas Valley of California from 2007 through 2010. Sixteen of these were nonreplicated strip trials in commercial fields comparing a reduced $\mathrm{N}$ fertilization regime with the growers' standard $\mathrm{N}$ fertilization program. Replicated comparisons of reduced $\mathrm{N}$ management strategies and growers' $\mathrm{N}$ management were conducted in five additional commercial fields. All commercial fields had been in long-term rotations of cool-season vegetables. The remaining three trials, conducted at a research facility, were replicated $\mathrm{N}$ rate comparisons.

Strip trials. Sixteen commercial lettuce fields were selected in 2009 and 2010 to evaluate the reliability of PSNT in identifying fields in which $\mathrm{N}$ fertilization could be reduced or delayed with no loss of marketable yield. The fields, which were seeded between 21 Mar. and 1 Aug., were selected based on the presence of at least $20 \mathrm{mg} \cdot \mathrm{kg}^{-1}$ $\mathrm{NO}_{3}-\mathrm{N}$ in the top $30 \mathrm{~cm}$ of soil after crop thinning (typically 14 to $21 \mathrm{~d}$ after planting); this soil $\mathrm{NO}_{3}-\mathrm{N}$ threshold was suggested by prior research on lettuce (Breschini and Hartz, 2002; Hartz et al., 2000). Twelve fields were planted with iceberg cultivars and four fields with romaine. The Salinas Valley is 
Soil Management, Fertilization, and Irrigation

Table 1. Effect of sidedress $\mathrm{N}$ reduction on aboveground lettuce fresh biomass, and biomass nitrogen (N), in the commercial strip trials.

\begin{tabular}{|c|c|c|c|c|c|c|c|c|c|c|}
\hline \multirow[b]{2}{*}{ Trial } & \multirow{2}{*}{$\begin{array}{l}\text { Lettuce } \\
\text { type }\end{array}$} & \multirow{2}{*}{$\begin{array}{l}\text { Germination } \\
\text { water date }\end{array}$} & \multirow{2}{*}{$\begin{array}{c}\text { Soil } \\
\text { texture }\end{array}$} & \multirow{2}{*}{$\begin{array}{l}\text { Soil } \mathrm{NO}_{3}-\mathrm{N} \\
\left(\mathrm{mg} \cdot \mathrm{kg}^{-1}\right)^{\mathrm{z}}\end{array}$} & \multicolumn{2}{|c|}{ Seasonal N $\left(\mathrm{kg} \cdot \mathrm{ha}^{-1}\right)$} & \multicolumn{2}{|c|}{ Fresh biomass $\left({\left.\mathrm{Mg} \cdot \mathrm{ha}^{-1}\right)}^{-1}\right.$} & \multicolumn{2}{|c|}{ Biomass N $\left(\mathrm{kg} \cdot \mathrm{ha}^{-1}\right)$} \\
\hline & & & & & Grower N & Reduced N & Grower N & Reduced N & Grower N & Reduced N \\
\hline 1 & Iceberg & 21 Mar. & Clay & 36 & 144 & 25 & 80 & 78 & 140 & 136 \\
\hline 2 & Iceberg & 1 Apr. & Silty clay & 20 & 138 & 40 & 109 & 101 & 190 & 177 \\
\hline 3 & Iceberg & 11 Apr. & Clay loam & 48 & 132 & 29 & 82 & 85 & 152 & 151 \\
\hline 4 & Iceberg & 30 May & Clay & 55 & 143 & 48 & 85 & 86 & 158 & 160 \\
\hline 5 & Iceberg & 22 June & Silty loam & 33 & 112 & 50 & 101 & 99 & 157 & 171 \\
\hline 6 & Iceberg & 1 July & Sandy clay loam & 20 & 203 & 115 & 107 & 107 & 174 & 168 \\
\hline 7 & Iceberg & 1 July & Silty clay loam & 24 & 89 & 36 & 85 & 85 & 145 & 146 \\
\hline 8 & Iceberg & 15 July & Sandy clay loam & 48 & 190 & 119 & 86 & 85 & 147 & 148 \\
\hline 9 & Iceberg & 16 July & Clay & 32 & 85 & 36 & 84 & 84 & 136 & 134 \\
\hline 10 & Iceberg & 16 July & Silty clay & 71 & 190 & 119 & 119 & 113 & 200 & 197 \\
\hline 11 & Iceberg & 1 Aug. & Clay & 46 & 144 & 25 & 126 & 128 & 189 & 188 \\
\hline 12 & Iceberg & 18 May & Clay loam & 36 & 216 & 151 & 71 & 71 & 95 & 91 \\
\hline 13 & Romaine & 6 June & Clay & 29 & 148 & 114 & 74 & 78 & 158 & 169 \\
\hline 14 & Romaine & 27 June & Sandy clay loam & 20 & 142 & 47 & 79 & 78 & 164 & 124 \\
\hline 15 & Romaine & 1 Aug. & Sandy clay loam & 23 & 148 & 98 & 77 & 76 & 136 & 120 \\
\hline 16 & Romaine & 1 Aug. & Clay & 68 & 179 & 108 & 74 & 75 & 152 & 139 \\
\hline Avg & & & & & 150 & 73 & 90 & 89 & 156 & 151 \\
\hline
\end{tabular}

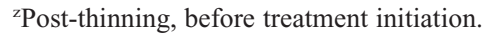

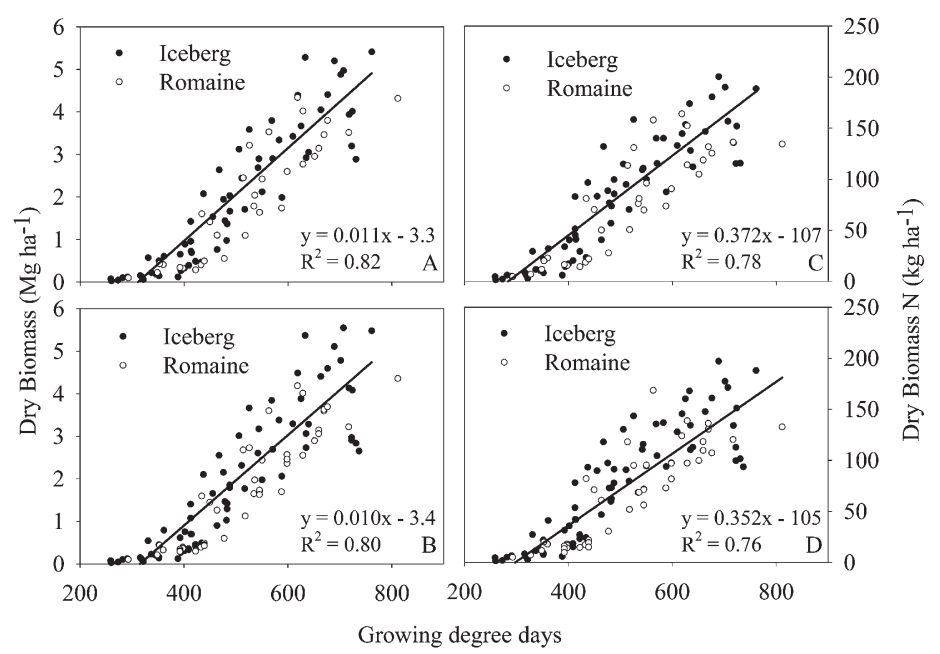

Fig. 1. Lettuce aboveground dry biomass, and dry biomass nitrogen $(\mathrm{N})$, as a function of cumulative growing degree-days in the strip trial fields; grower $\mathrm{N}$ treatment $(\mathbf{A}$ and $\mathbf{C})$ and reduced $\mathrm{N}$ treatment $(\mathbf{B}$ and D). Growing degree-days were calculated using 5 and $30^{\circ} \mathrm{C}$ threshold temperatures.

essentially rain-free during the lettuce production period, and growers use a variety of irrigation systems and irrigation schedules. Most fields are irrigated with well water. Wells vary widely in $\mathrm{NO}_{3}-\mathrm{N}$ concentration with most wells between 2 and $20 \mathrm{mg} \cdot \mathrm{L}^{-1}$. All fields were sprinkler-irrigated for stand establishment with two fields switched to drip irrigation and one field switched to furrow irrigation after establishment. Soil texture ranged from sandy clay loam to clay. The planting configuration was either two plant rows per 1-m raised bed or five to six plant rows per 2-m raised bed; plant population varied from 72,000 to 112,000 ha. Preplant N fertilization was banded in the beds at rates ranging from 0 to $40 \mathrm{~kg} \cdot \mathrm{ha}^{-1}$.

Before the first sidedress $\mathrm{N}$ application, a strip plot in the center of each field was identified to receive a reduced $\mathrm{N}$ fertilization regime. These strip plots were the length of the field $\times 12$ to 24 beds wide and averaged 0.4 ha. The width of the strip plot was set to accommodate one pass of the commercial harvest crew and equipment, which varied by grower. In all fields, the grower applied an $\mathrm{N}$ sidedressing 20 to $28 \mathrm{~d}$ after planting. Sidedress applications were typically applied in bands 5 to $10 \mathrm{~cm}$ deep in the bed; a variety of $\mathrm{N}$ fertilizers were used. The strip plot received either no sidedressing (14 fields) or a half rate sidedressing (two fields) at the cooperating growers' discretion. After the first sidedressing, the reduced $\mathrm{N}$ plots received all subsequent $\mathrm{N}$ fertilization applied by the grower, whether by additional sidedressing or by fertigation.

Soil samples (0 to $30 \mathrm{~cm}$ depth in the plant row) were taken before the first $\mathrm{N}$ sidedressing and repeated on 7- to 10-d intervals until harvest. Samples were collected separately from the head and tail ends of the reduced $\mathrm{N}$ plot. Samples of the grower $\mathrm{N}$ regime from the head and tail ends of the field were collected from the areas adjacent to the reduced $\mathrm{N}$ plot; samples drawn from each side of the reduced $\mathrm{N}$ plot were blended so that for each sampling date, a total of four composite samples per field was collected; each comprised of eight to 10 cores. Matching samples of whole plants and recently mature leaves were also collected at each soil sampling date after the initial $\mathrm{N}$ sidedressing. Each of the four composite samples per field per collection date contained 12 whole plants and 20 leaves; the leaves were subsequently divided into blade and midrib samples. Plant, leaf, and midrib samples were oven-dried at $65^{\circ} \mathrm{C}$ to a constant weight and ground to pass a 40 mesh screen. $N$ concentration of whole plants and leaf blades was determined by a $\mathrm{N}$ gas analyzer (Model FP-528; LECO Corp., St. Joseph, MI). Midrib $\mathrm{NO}_{3}-\mathrm{N}$ was measured by flow injection analysis (Lachat Instruments, Milwaukee, WI) after extraction with $2 \%$ acetic acid. Field-moist soil was extracted in $2 \mathrm{~N} \mathrm{KCl}$ and analyzed for $\mathrm{NO}_{3}-\mathrm{N}$ by the flow injection method. Plant population was determined based on post-thinning plant counts in four representative $4 \mathrm{~m}$ wide $\times$ 30 -m long strips within the trial area of each field.

Just before commercial harvest, aboveground biomass was determined by the collection of 32 randomly selected whole plants in both the head and tail ends of the reduced $\mathrm{N}$ plot and in the adjacent grower $\mathrm{N}$ plots, as previously described. Subsamples were oven-dried, weighed, and analyzed for total $\mathrm{N}$ concentration. During the commercial harvest, the harvest crews recorded marketable yield separately in the reduced $\mathrm{N}$ strip and in the adjacent areas receiving the full grower $\mathrm{N}$ regime.

Replicated trials. Five replicated field trials were conducted in drip-irrigated commercial lettuce fields between 2007 and 2009. Three fields were planted with iceberg and two fields with romaine cultivars. All of the fields were sprinkler-irrigated for stand establishment and then switched to drip irrigation. Soil texture ranged from loam to clay loam. Fields were planted between 3 Mar. and 2 Aug. $N$ fertilization treatments differed among fields based on the grower practices. Within fields, up to four levels of seasonal $\mathrm{N}$ application were established by eliminating 
Table 2. Effect of nitrogen $(\mathrm{N})$ fertigation on lettuce fresh biomass, and biomass $\mathrm{N}$, in the replicated commercial drip-irrigated trials.

\begin{tabular}{|c|c|c|c|c|c|c|c|c|c|c|}
\hline Trial & Yr & $\begin{array}{l}\text { Lettuce } \\
\text { type }\end{array}$ & $\begin{array}{c}\text { Germination } \\
\text { water date }\end{array}$ & $\begin{array}{c}\text { Soil } \\
\text { texture }\end{array}$ & $\begin{array}{l}\text { Soil NO} \mathrm{NO}_{3}-\mathrm{N} \\
\left(\mathrm{mg} \cdot \mathrm{kg}^{-1}\right)^{\mathrm{z}}\end{array}$ & $\mathrm{N}$ treatment & $\begin{array}{l}\text { Number of } \\
\text { fertigations }\end{array}$ & $\begin{array}{c}\text { Seasonal N } \\
\left(\mathrm{kg} \cdot \mathrm{ha}^{-1}\right)\end{array}$ & $\begin{array}{c}\text { Fresh biomass } \\
\left(\mathrm{Mg} \cdot \mathrm{ha}^{-1}\right)\end{array}$ & $\begin{array}{c}\text { Biomass N } \\
\left(\mathrm{kg} \cdot \mathrm{ha}^{-1}\right)\end{array}$ \\
\hline & & & & & & Reduced 1 & 1 & 103 & $93 \mathrm{a}$ & $102 \mathrm{~b}$ \\
\hline & & & & & & Reduced 2 & 0 & 47 & $81 \mathrm{~b}$ & $94 \mathrm{~b}$ \\
\hline & & & & & & Reduced 1 & 2 & 72 & $91 \mathrm{a}$ & $113 \mathrm{a}$ \\
\hline & & & & & & Reduced 2 & 0 & 20 & $83 \mathrm{a}$ & $100 \mathrm{a}$ \\
\hline 3 & 2007 & Romaine & 15 Aug & Loam & 21 & Grower & 2 & 129 & $77 \mathrm{a}$ & $114 \mathrm{a}$ \\
\hline & & & & & & Reduced 2 & 2 & 140 & $92 \mathrm{a}$ & $111 \mathrm{a}$ \\
\hline & & & & & & Reduced 3 & 1 & 86 & $84 \mathrm{~b}$ & $108 \mathrm{a}$ \\
\hline \multirow[t]{2}{*}{5} & 2009 & Romaine & 2 Aug & Loam & 21 & Grower & 3 & 175 & $77 \mathrm{a}$ & $134 \mathrm{a}$ \\
\hline & & & & & & Reduced & 3 & 144 & $77 \mathrm{a}$ & $132 \mathrm{a}$ \\
\hline
\end{tabular}

zPost-thinning, before treatment initiation.

${ }^{y}$ Means within columns and trials separated using the REGWQ multiple range test.
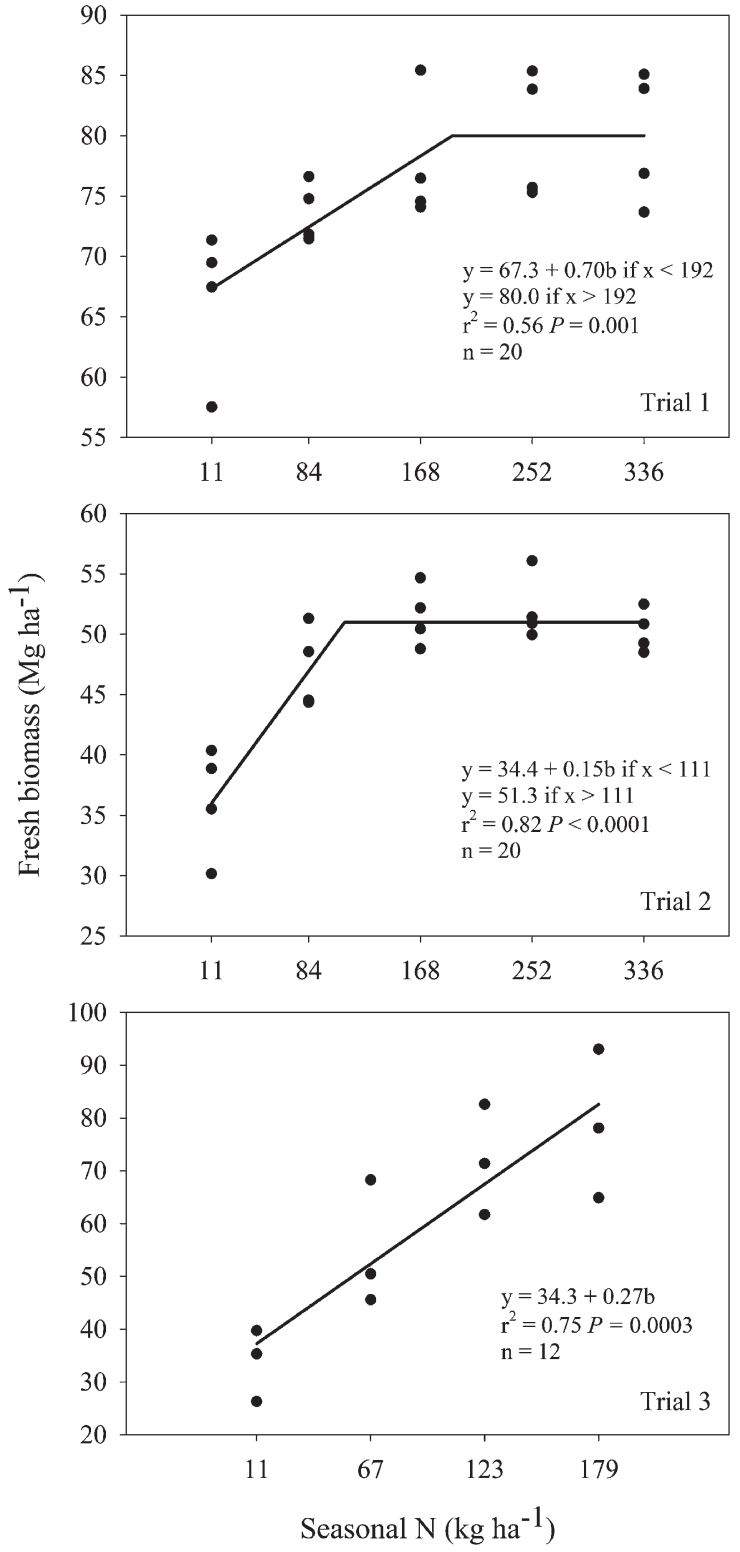

Fig. 2. Lettuce fresh biomass as affected by seasonal nitrogen $(\mathrm{N})$ rate in research farm trials; linear-plateau models fit by the method of Waugh et al. (1973).

one or more of the grower $\mathrm{N}$ fertigations. All fields had soil $\mathrm{NO}_{3}-\mathrm{N}$ greater than $20 \mathrm{mg} \cdot \mathrm{kg}^{-1}$ (0 to $30 \mathrm{~cm} \mathrm{depth)} \mathrm{at} \mathrm{the} \mathrm{time} \mathrm{of} \mathrm{the} \mathrm{initial}$

in-season $\mathrm{N}$ application. A randomized complete block experimental design was used in all fields with four replications per $\mathrm{N}$ treatment. Individual plots were four $1-\mathrm{m}$ beds wide $\times 9$ to $15 \mathrm{~m}$ long. Data were collected on the middle two beds of each plot. Soil, whole plant, leaf, and midrib sampling was done on 7 - to 10-d intervals as previously described. The final plant sampling was conducted just before commercial harvest. Fresh and dry biomass of 24 randomly selected whole plants per plot was determined.

Three additional $\mathrm{N}$ rate trials were conducted between 2009 and 2010 at the Hartnell College research farm in Salinas, CA. All trials were seeded with romaine cultivars and grown using drip irrigation. Each trial was organized in a randomized complete block design with four replications (Trials 1 and 2) or three replications (Trial 3) per $\mathrm{N}$ rate. Each plot consisted of two $1 \mathrm{~m}$ wide beds $50 \mathrm{~m}$ long. Seasonal $\mathrm{N}$ rates ranged from 11 to $336 \mathrm{~kg} \cdot \mathrm{ha}^{-1}$ (Trials 1 and 2) and from 11 to $179 \mathrm{~kg} \cdot \mathrm{ha}^{-1}$ (Trial 3). N was applied preplant $\left(11 \mathrm{~kg} \cdot \mathrm{ha}^{-1}\right)$ and in three fertigations at $\approx 4,5$, and 6 weeks post-planting. Soil $\mathrm{NO}_{3}-\mathrm{N}(0$ to $30 \mathrm{~cm}$ depth) at the first $\mathrm{N}$ fertigation was 13, 9, and $7 \mathrm{mg} \cdot \mathrm{kg}^{-1}$ in Fields 1, 2, and 3, respectively. At commercial maturity, aboveground biomass was determined on 80 randomly selected whole plants per plot.

Calculation of growing degree-days. To allow comparison of lettuce growth across fields and production seasons, growing degreedays (GDDs) were calculated from air temperature data provided by the California Irrigation Management Information System (Pruitt et al., 1987). GDDs were calculated using a single sine method (Allen, 1976) with upper and lower thresholds of 30 and $5{ }^{\circ} \mathrm{C}$, respectively. GDD accumulation began on the day of the first irrigation rather than at seeding because seeding was typically done in dry soil.

Statistical analysis. Parallel line analysis was used to compare the regression slopes of romaine and iceberg lettuce dry biomass accumulation over time using SigmaPlot (Systat Software, Inc., San Jose, CA). All other statistical analyses were conducted using the SAS statistical package (SAS Institute, Cary, NC). Comparison of the crop biomass of the grower and reduced $\mathrm{N}$ management treatments in the strip trials was 
done with the GLM procedure using fields as replications to evaluate the reliability of the $20 \mathrm{mg} \cdot \mathrm{kg}^{-1}$ PSNT residual soil $\mathrm{NO}_{3}-\mathrm{N}$ threshold as a diagnostic tool to improve $\mathrm{N}$ management. Comparison of lettuce biomass among $\mathrm{N}$ treatments in the replicated commercial trials was accomplished using the GLM procedure and the REGWQ multiple range test. Optimum $\mathrm{N}$ rates in the research farm trials were estimated by the linearplateau model described by Waugh et al. (1973) using the NLIN procedure.

\section{Results}

Aboveground lettuce fresh biomass in the reduced $\mathrm{N}$ treatment was not different from the grower $\mathrm{N}$ management treatment in the strip trials $(P=0.92)$, confirming the reliability of PSNT in identifying fields in which the first sidedress $\mathrm{N}$ application could be reduced or delayed (Table 1). Across the 16 fields, total fresh biomass at harvest averaged 89.9 and $89.3 \mathrm{Mg} \cdot \mathrm{ha}^{-1}$ in the grower $\mathrm{N}$ and reduced $\mathrm{N}$ treatments, respectively. Marketable yield was obtained from the commercial harvest crews in 12 of the fields, and the reduced $\mathrm{N}$ treatment averaged $41.0 \mathrm{Mg} \cdot \mathrm{ha}^{-1}$ compared with $40.8 \mathrm{Mg} \cdot \mathrm{ha}^{-1}$ in the grower $\mathrm{N}$ treatment $(P=0.97)$. Seasonal $\mathrm{N}$ application (including preplant fertilization) averaged 150 and $73 \mathrm{~kg} \cdot \mathrm{ha}^{-1}$ in the grower $\mathrm{N}$ and reduced $\mathrm{N}$ treatments, respectively. Aboveground biomass $\mathrm{N}$ in the reduced $\mathrm{N}$ treatment averaged $151 \mathrm{~kg} \cdot \mathrm{ha}^{-1}$ compared with $156 \mathrm{~kg} \cdot \mathrm{ha}^{-1}$ in the grower $\mathrm{N}$ treatment, suggesting inefficient use of the $\mathrm{N}$ applied at first sidedressing, which averaged $77 \mathrm{~kg} \cdot \mathrm{ha}^{-1}$.

Lettuce showed a characteristic growth pattern across the strip trial fields (Fig. 1A-B). Aboveground dry biomass accumulation averaged less than $0.3 \mathrm{Mg} \cdot \mathrm{ha}^{-1}$ over the first 300 GDD $(\approx 3$ to 4 weeks at Salinas Valley temperatures) and then increased in a linear fashion until harvest. There was no significant difference between iceberg and romaine lettuce in DM accumulation [regression slopes during the rapid growth phase were not significantly different $(P=0.51)]$. There was a trend toward higher DM with increasing plant population $\left[\mathrm{DM}\left(\mathrm{Mg} \cdot \mathrm{ha}^{-1}\right)=0.00003\right.$ (plants/ha) $\left.+1.44, r^{2}=0.14, P=0.08\right]$. Biomass $\mathrm{N}$ accumulation followed the same pattern as biomass accumulation (Fig. 1C-D). N uptake during the linear growth phase averaged 0.38 $\mathrm{kg} / \mathrm{GDD}$ across $\mathrm{N}$ treatments and fields; at 10 to $12 \mathrm{GDD} / \mathrm{d}$ during the production season, daily aboveground $\mathrm{N}$ accumulation averaged $\approx 3.8$ to $4.6 \mathrm{~kg} \cdot \mathrm{ha}^{-1}$.

The replicated commercial trials also demonstrated that $\mathrm{N}$ fertigation could be reduced below current grower practice with no reduction in crop biomass (Table 2). Significant fresh biomass reduction was observed in only two of five fields and only in treatments in which multiple $\mathrm{N}$ fertigations were eliminated. In both cases of biomass reduction, the midseason soil $\mathrm{NO}_{3}-\mathrm{N}$ had decreased to less than $10 \mathrm{mg} \cdot \mathrm{kg}^{-1}$. A significant response to $\mathrm{N}$ fertigation was observed in all research farm trials (Fig. 2). Seasonal N rates between 111 and $192 \mathrm{~kg} \cdot \mathrm{ha}^{-1}$ were sufficient to maximize fresh biomass, somewhat higher than observed in the other trials. The research farm trials began with lower residual soil $\mathrm{NO}_{3}-\mathrm{N}$ (7 to $13 \mathrm{mg} \cdot \mathrm{kg}^{-1}$ ), and they followed a fallow period, whereas most of the commercial fields were planted after residue incorporation from a spring crop.

Collectively, these 24 trials provided extensive data on lettuce growth and plant $\mathrm{N}$ status on which to apply the "critical N concentration" concept $\left(\mathrm{N}_{\mathrm{c}}\right.$, the minimum whole plant $\mathrm{N}$ concentration required to maximize growth; Greenwood et al., 1991; Fig. 3). Data points identified as N-deficient represented treatments in replicated trials in which DM was significantly $(P<0.05)$ below that of the highest $\mathrm{N}$ rate in that trial on a given sample date. Data points identified as "grower N" represented the grower N management in the strip trials and the replicated commercial trials plus the highest $\mathrm{N}$ rate in the research farm trials. Points identified as "reduced N" represented reduced N treatments from all strip trials plus reduced $\mathrm{N}$ treatments from replicated trials for which
DM was not statistically different $(P>0.05)$ from the grower $\mathrm{N}$ treatment on a given sample date. The critical $\mathrm{N}$ equation $\left[\mathrm{N}_{\mathrm{c}}=\right.$ 45.6 DM $\left.\left(\mathrm{Mg} \cdot \mathrm{ha}^{-1}\right)^{-0.357}\right]$, developed in a 3 year study of lettuce in Italy by Tei et al. (2003), generally distinguished $\mathrm{N}$ deficiency from sufficiency. However, that equation had been validated only for DM values between 0.9 and 3.4 Mg.ha ${ }^{-1}$ and was clearly inappropriate for earlier growth stages. We empirically fit a linear function $\left(\mathrm{N}_{\mathrm{c}}=42.0-2.8\right.$ $\mathrm{DM})$, which distinguished $\mathrm{N}$-deficient from $\mathrm{N}$-sufficient samples with reasonable accuracy across the entire season.

Based on the empirically derived $\mathrm{N}_{\mathrm{c}}$ equation, the crop $\mathrm{N}$ uptake required to maintain whole plant $\mathrm{N}$ above the $\mathrm{N}_{\mathrm{c}}$ (critical $\mathrm{N}$ uptake, $\mathrm{N}_{\text {upt }}=-2.8 \mathrm{DM}^{2}+42 \mathrm{DM}$ ) was compared with actual crop $\mathrm{N}$ uptake of the grower $\mathrm{N}$ treatment in the commercial field trials (Fig. 4). Aboveground DM at harvest in the grower $\mathrm{N}$ treatment ranged from 2.4 to $5.4 \mathrm{Mg} \cdot \mathrm{ha}^{-1}$, and $\mathrm{N}$ uptake ranged from 94 to $200 \mathrm{~kg} \cdot \mathrm{ha}^{-1}$, averaging $145 \mathrm{~kg} \cdot \mathrm{ha}^{-1}$. The calculated $\mathrm{N}_{\text {upt }}$ ranged from 86 to $145 \mathrm{~kg} \cdot \mathrm{ha}^{-1}$, averaging only $116 \mathrm{~kg} \cdot \mathrm{ha}^{-1}$, indicating that a substantial amount of "luxury" uptake occurred

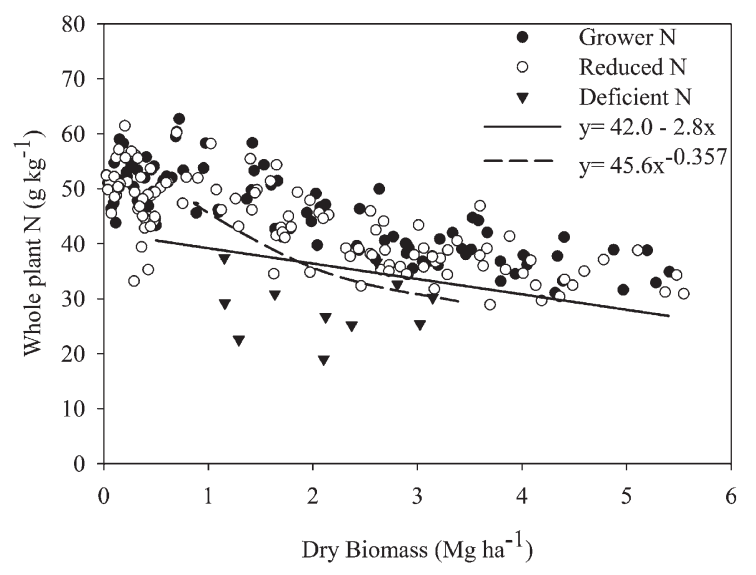

Fig. 3. The relationship between dry biomass $(\mathrm{DM})$ and whole plant nitrogen $(\mathrm{N})$ concentration. Dashed line represents plant critical $\mathrm{N}$ concentration $\left(\mathrm{N}_{\mathrm{c}}=45.6 \mathrm{DM}^{-0.357}\right)$ from Tei et al. (2003). Solid line represents $\mathrm{N}_{\mathrm{c}}$ as an empirically derived linear function $\left(\mathrm{N}_{\mathrm{c}}=42.0-2.8 \mathrm{DM}\right)$.

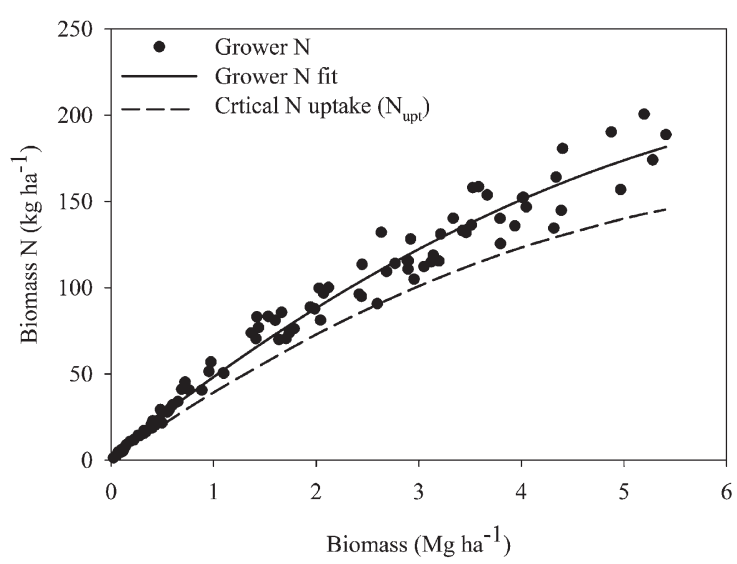

Fig. 4. Whole plant nitrogen (N) (all commercial field trials) as function of dry biomass (DM) for grower $\mathrm{N}$ treatment. Solid line represents grower $\mathrm{N}$ uptake $\left(\mathrm{y}=-2.8 \mathrm{DM}^{2}+48 \mathrm{DM}+3\right)$; dashed line represents critical $\mathrm{N}$ uptake $\left(\mathrm{N}_{\text {upt }}, \mathrm{y}=-2.8 \mathrm{DM}^{2}+42 \mathrm{DM}\right)$. 
in these fields. $\mathrm{N}_{\text {upt }}$ during the rapid growth phase ranged between 3 and $4 \mathrm{~kg} \cdot \mathrm{ha}^{-1} \cdot \mathrm{d}^{-1}$ for Salinas Valley summer conditions.

Neither leaf $\mathrm{N}$ nor midrib $\mathrm{NO}_{3}-\mathrm{N}$ was correlated with concurrently measured soil $\mathrm{NO}_{3}-\mathrm{N}$ during either early growth (less than $1.5 \mathrm{Mg} \cdot \mathrm{ha}^{-1}$ biomass) or the heading stage (greater than $1.5 \mathrm{Mg} \cdot \mathrm{ha}^{-1}$; Fig. 5). This insensitivity across a wide range of soil $\mathrm{NO}_{3}-\mathrm{N}$ suggested that these tissue diagnostics provided no insight on current soil $\mathrm{N}$ availability. Leaf $\mathrm{N}$ was correlated with whole plant N (Fig. 6A). However, there was substantial variability in that relationship, indicating that leaf $\mathrm{N}$ was not a dependable surrogate for whole plant N. Midrib $\mathrm{NO}_{3}-\mathrm{N}$ was not correlated with whole plant $\mathrm{N}$ (Fig. 6B). Based on the limited number of $\mathrm{N}$-deficient leaf and midrib samples encountered in this study, empirically derived critical levels appeared to be $\approx 40 \mathrm{~g} \cdot \mathrm{kg}^{-1}$ leaf $\mathrm{N}$ and $6 \mathrm{~g} \cdot \mathrm{kg}^{-1}$ midrib $\mathrm{NO}_{3}-\mathrm{N}$ throughout the season (Fig. 7). However, the separation between deficient and sufficient samples was not clear, and applying these critical levels would have resulted in unnecessary fertilization in some fields. Given the limitations just described, using either tissue $\mathrm{N}$ diagnostic to guide $\mathrm{N}$ fertilization, in the absence of soil $\mathrm{NO}_{3}-\mathrm{N}$ data, would not be warranted.

The average soil $\mathrm{NO}_{3}-\mathrm{N}$ concentration in the top $30 \mathrm{~cm}$ at harvest in the strip trials was 20 and $14 \mathrm{mg} \cdot \mathrm{kg}^{-1}$ for the grower $\mathrm{N}$ and reduced $\mathrm{N}$ treatments, respectively (Fig. 8). This difference in soil $\mathrm{NO}_{3}-\mathrm{N}$ of $6 \mathrm{mg} \cdot \mathrm{kg}^{-1}$ represented $23 \mathrm{~kg} \mathrm{~N} / \mathrm{ha}$ in the top $30 \mathrm{~cm}$, assuming a typical bulk density of $1.4 \mathrm{~g} \cdot \mathrm{cm}^{-3}$. Taking into account the slight increase in crop $\mathrm{N}$ uptake $\left(\approx 5 \mathrm{~kg} \cdot \mathrm{ha}^{-1}\right)$ obtained in the grower $\mathrm{N}$ treatment in these fields, less than half of the extra $77 \mathrm{~kg} \cdot \mathrm{ha}^{-1} \mathrm{~N}$ applied in that treatment was accounted for at harvest, suggesting substantial in-season leaching below $30 \mathrm{~cm}$. At harvest, soil $\mathrm{NO}_{3}-\mathrm{N}$ was less than $10 \mathrm{mg} \cdot \mathrm{kg}^{-1}$ in the reduced-N treatment in nine of the 14 fields in which data were collected and below that level in the grower $\mathrm{N}$ treatment in six fields. This documented that high-yield lettuce production can be managed to minimize residual soil $\mathrm{NO}_{3}-\mathrm{N}$ at the end of the season.

\section{Discussion}

Lettuce growth was maximized by seasonal $\mathrm{N}$ fertilization rates substantially below current typical grower practices. The reduced $\mathrm{N}$ treatment in the strip plot trials received an average of only $73 \mathrm{~kg} \mathrm{~N} / \mathrm{ha}$ and produced biomass equivalent to the more heavily fertilized grower $\mathrm{N}$ treatment. In the replicated commercial fertigation trials, the lowest seasonal $\mathrm{N}$ rate achieving maximum biomass averaged only $102 \mathrm{~kg} \mathrm{~N} / \mathrm{ha}$. The presence of high residual soil $\mathrm{NO}_{3}-\mathrm{N}$ in these fields, which is common in this production system (especially after a spring crop), was a major factor limiting fertilizer $\mathrm{N}$ requirements. In the absence of substantial residual soil $\mathrm{NO}_{3}-\mathrm{N}$, fertilizer $\mathrm{N}$ requirements would undoubtedly
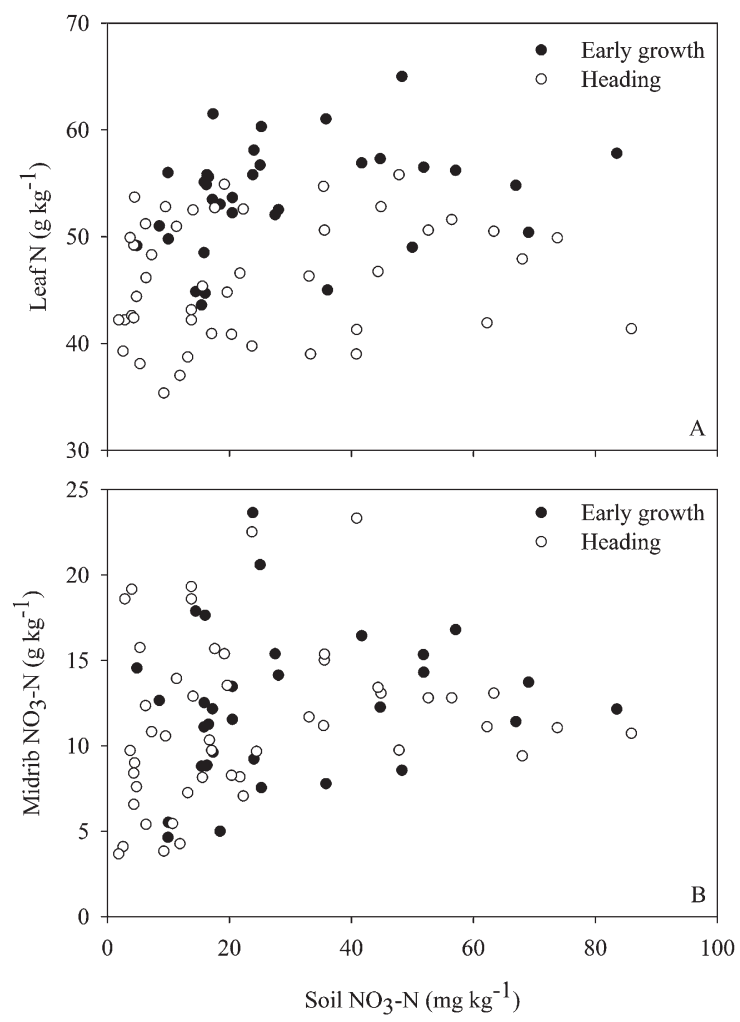

Fig. 5. Relationship between root zone soil $\mathrm{NO}_{3}-\mathrm{N}$ and leaf nitrogen $(\mathrm{N})(\mathbf{A})$ or midrib $\mathrm{NO}_{3}-\mathrm{N}(\mathbf{B})$. Early growth and heading stages defined as dry biomass less than $1.5 \mathrm{Mg} \cdot \mathrm{ha}^{-1}$ and greater than $1.5 \mathrm{Mg} \cdot \mathrm{ha}^{-1}$, respectively.

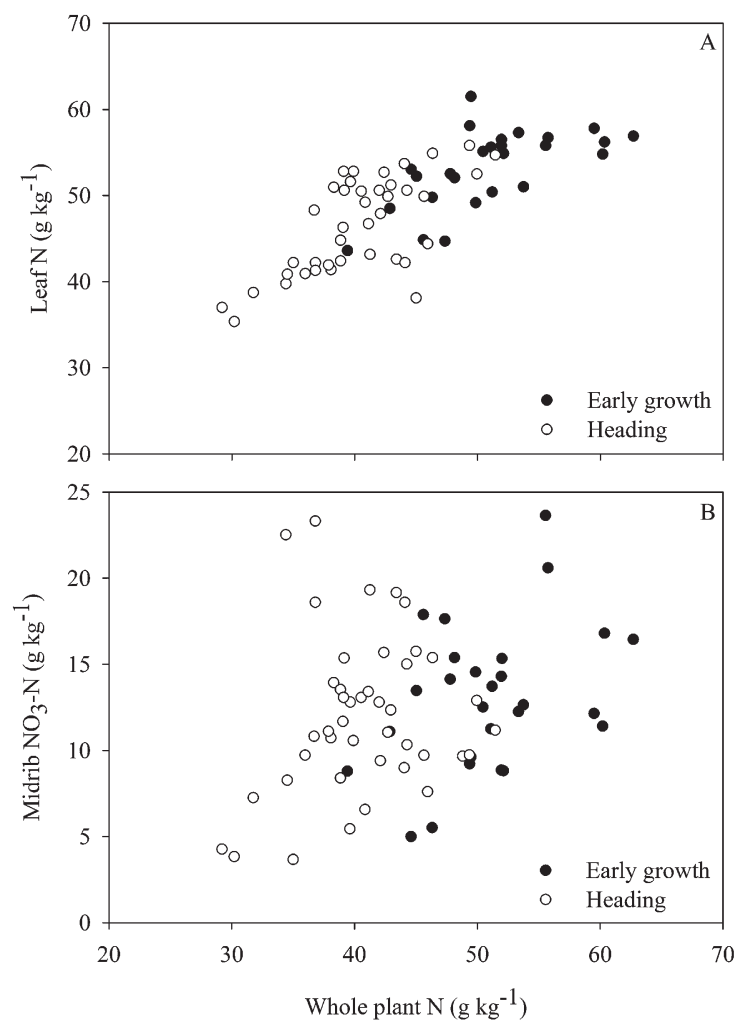

Fig. 6. Relationship between whole plant nitrogen $(\mathrm{PN})$ concentration and leaf $\mathrm{N}(\mathrm{LN})$ concentration at the early growth $\left(\mathrm{LN}=0.50 \mathrm{PN}+27.9, r^{2}=0.40\right)$ and heading stages $\left(\mathrm{LN}=0.76 \mathrm{PN}+15.7, r^{2}=0.46, \mathbf{A}\right)$. Relationship between $\mathrm{PN}$ concentration and midrib $\mathrm{NO}_{3}-\mathrm{N}$ concentration at the early growth and heading stages (B). Early growth and heading stages defined as dry biomass less than $1.5 \mathrm{Mg} \cdot \mathrm{ha}^{-1}$ and greater than $1.5 \mathrm{Mg} \cdot \mathrm{ha}^{-1}$, respectively. 

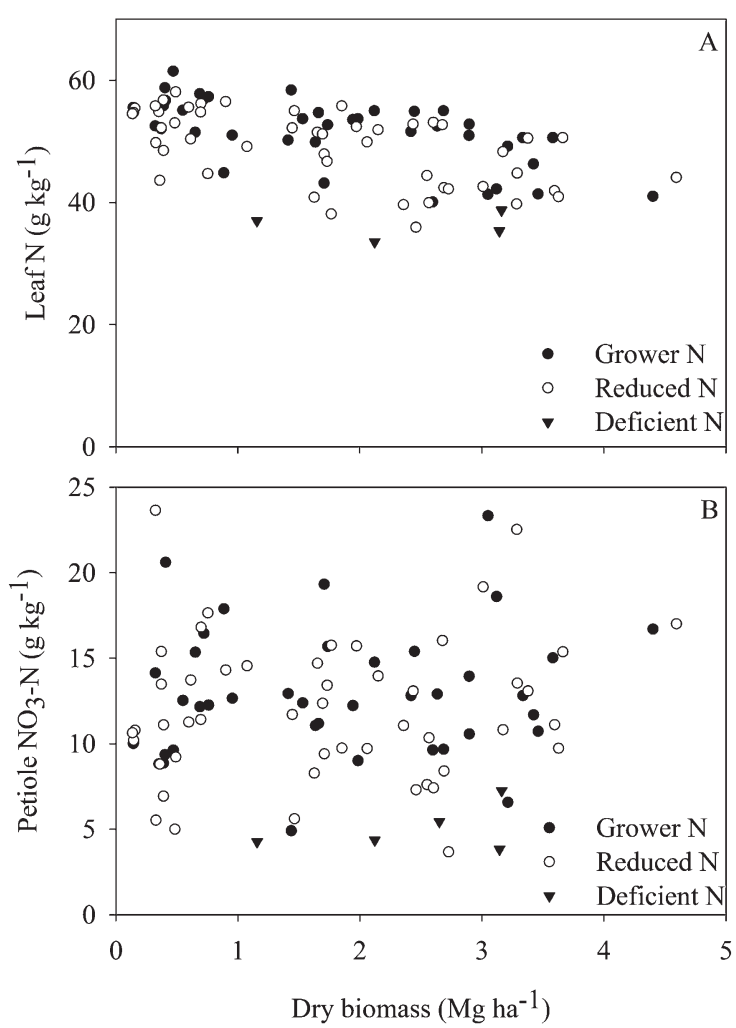

Fig. 7. Leaf nitrogen (N) (A) and midrib $\mathrm{NO}_{3}-\mathrm{N}(\mathbf{B})$ as a function of dry biomass; data include all growth stages from all fields.

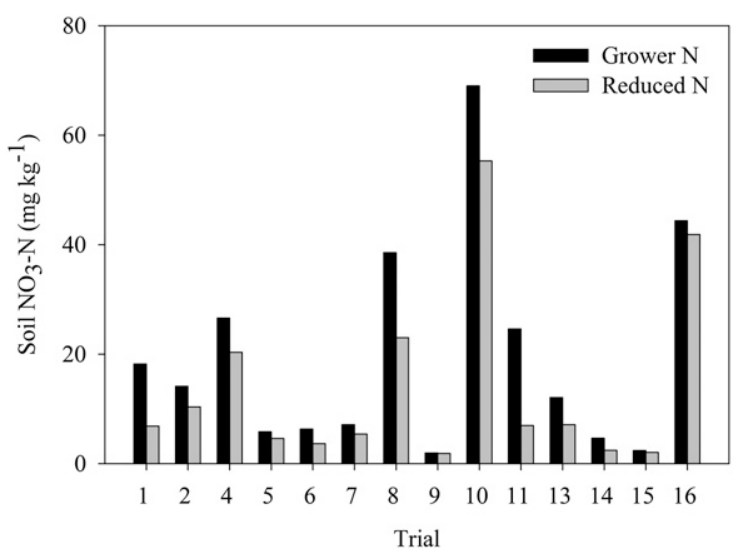

Fig. 8. Residual soil $\mathrm{NO}_{3}-\mathrm{N}$ in the surface $30 \mathrm{~cm}$ at harvest in the strip trial fields.

be higher, as was the case in the research farm trials.

Crop uptake of the extra $\mathrm{N}$ applied in the grower $\mathrm{N}$ treatment was minimal. On average the apparent fertilizer recovery (AFR) of the $\mathrm{N}$ applied by growers at the first sidedressing was only $7 \%$ in the strip trials. In the replicated commercial fertigation trials, crop $\mathrm{N}$ uptake in the grower $\mathrm{N}$ treatment was on average only $13 \mathrm{~kg} \cdot \mathrm{ha}^{-1}$ higher than the lowest reduced $\mathrm{N}$ treatment that produced equivalent biomass, representing an AFR of $16 \%$ for the extra $\mathrm{N}$ applied by growers. Greenwood et al. (1989) reported that AFR in lettuce declined as $\mathrm{N}$ rate increased; at $\mathrm{N}$ rates greater than $100 \mathrm{~kg} \cdot \mathrm{ha}^{-1}$, AFR was less than $15 \%$. In this production system where multiple crops are produced annually, the overall AFR of $\mathrm{N}$ applied to a spring crop may be improved by subsequent recovery by a summer-planted crop. However, lettuce is shallowly rooted with most roots concentrated in the top $30 \mathrm{~cm}$ of soil (Jackson, 1995). The potential for $\mathrm{NO}_{3}-\mathrm{N}$ leaching during the germination irrigation for the summer crop is substantial, and leaching losses with winter precipitation would be even more significant. Jackson et al. (1994) found that annual $\mathrm{NO}_{3}-\mathrm{N}$ leaching loss in a double-cropped lettuce field in the Salinas Valley was $\approx 150 \mathrm{~kg} \cdot \mathrm{ha}^{-1}$.

The reliability of PSNT in identifying lettuce fields in which $\mathrm{N}$ sidedressing can be reduced or delayed confirmed earlier
California studies (Breschini and Hartz, 2002; Hartz et al., 2000). PSNT has been successfully applied to other crops, including cabbage (Brassica oleracea L. var. capitata L.; Heckman et al., 2002), celery (Apium graveolens L.; Hartz et al., 2000), and corn (Zea mays L.; Fox et al., 1989; Heckman et al., 1995); action thresholds have ranged from 20 to $30 \mathrm{mg} \cdot \mathrm{kg}^{-1}$ soil $\mathrm{NO}_{3}-\mathrm{N}$. Most prior research on PSNT evaluated this approach as a once per season test to determine sidedress $\mathrm{N}$ requirements. However, for high-value vegetable crops on which multiple in-season $\mathrm{N}$ applications are common, repeated soil testing would allow growers more flexibility and confidence. Breschini and Hartz (2002) successfully demonstrated such a system in lettuce, testing soil $\mathrm{NO}_{3}-\mathrm{N}$ up to three times per crop and on each occasion applying only enough $\mathrm{N}$ to bring the soil up to a $20 \mathrm{mg} \cdot \mathrm{kg}^{-1}$ $\mathrm{NO}_{3}-\mathrm{N}$ threshold.

Based on the observed lettuce $\mathrm{N}$ uptake requirements in the weeks before harvest ( 3 to $4 \mathrm{~kg} \cdot \mathrm{ha}^{-1} \cdot \mathrm{d}^{-1}$ ), and the assumption that most $\mathrm{N}$ uptake occurs in the top $30 \mathrm{~cm}$ of soil, plant $\mathrm{N}$ uptake would be expected to reduce root zone soil $\mathrm{NO}_{3}-\mathrm{N}$ by no more than 1 $\mathrm{mg} \cdot \mathrm{kg}^{-1} \cdot \mathrm{d}^{-1}$. Soil testing for the final time 2 weeks before expected harvest, and limiting $\mathrm{N}$ application to no more than the amount required to return the soil to $20 \mathrm{mg} \cdot \mathrm{kg}^{-1} \mathrm{NO}_{3}$ $\mathrm{N}$, should provide sufficient mineral $\mathrm{N}$ for maximum crop productivity while finishing the season with a moderate level of residual soil $\mathrm{NO}_{3}-\mathrm{N}$. The observation that soil $\mathrm{NO}_{3}-\mathrm{N}$ at harvest in the reduced $\mathrm{N}$ treatment was less than $10 \mathrm{mg} \cdot \mathrm{kg}^{-1}$ in most fields confirmed that such low season-ending soil $\mathrm{NO}_{3}-\mathrm{N}$ was not growth-limiting. Minimizing residual soil $\mathrm{NO}_{3}-\mathrm{N}$ at harvest is a crucial element in a groundwater protection program.

In contrast to the documented use of soil $\mathrm{NO}_{3}-\mathrm{N}$ monitoring to guide in-season $\mathrm{N}$ fertilization, plant-based diagnostics were less useful. The close agreement of our data with that of Tei et al. (2003) regarding $\mathrm{N}_{c}$ suggested that whole plant $\mathrm{N}$ was a robust measure of $\mathrm{N}$ sufficiency. Early-season whole plant $\mathrm{N}$ could be a practical monitoring technique, and our empirical $\mathrm{N}_{\mathrm{c}}$ equation suggested a pre-heading critical threshold of $\approx 40 \mathrm{~g} \cdot \mathrm{kg}^{-1}$. As plants get larger, whole plant sampling becomes impractical. The correlation between leaf $\mathrm{N}$ and whole plant $\mathrm{N}$ was unsatisfactory to make it a precise surrogate for whole plant $\mathrm{N}$. Leaf $\mathrm{N}$ was not correlated with soil $\mathrm{NO}_{3}-\mathrm{N}$ over a range of soil values from very high (greater than $40 \mathrm{mg} \cdot \mathrm{kg}^{-1}$ ) to potentially growth-limiting (less than $5 \mathrm{mg} \cdot \mathrm{kg}^{-1}$ ). Maier et al. (1990) and Westerveld et al. (2003) found that leaf $\mathrm{N}$ critical level varied by cultivar and location. Such confounding effects may explain the variability in published diagnostic guidelines. Lorenz and Tyler (1983) reported a leaf $\mathrm{N}$ sufficiency threshold for lettuce at harvest of $25 \mathrm{~g} \cdot \mathrm{kg}^{-1}$, whereas Jones et al. (1991) suggested $38 \mathrm{~g} \cdot \mathrm{kg}^{-1}$. Our data agreed with Jones et al.

The practical value of midrib $\mathrm{NO}_{3}-\mathrm{N}$ monitoring was particularly questionable. Midrib $\mathrm{NO}_{3}-\mathrm{N}$ was unrelated to either soil 
$\mathrm{NO}_{3}-\mathrm{N}$ or whole plant N. Midrib (petiole) $\mathrm{NO}_{3}-\mathrm{N}$ has been shown to be affected by environmental conditions unrelated to soil $\mathrm{N}$ availability (Bates, 1971; Maynard et al., 1976) or to crop N uptake (MacKerron et al., 1995). The much higher degree of variability in midrib $\mathrm{NO}_{3}-\mathrm{N}$ encountered in the present study (samples ranged from 4 to $24 \mathrm{~g} \cdot \mathrm{kg}^{-1}$ ) compared with either whole plant $\mathrm{N}$ or leaf $\mathrm{N}$ suggested that the rate of nitrate reduction in the plant was influenced by factors unrelated to soil $\mathrm{NO}_{3}-\mathrm{N}$ availability or plant $\mathrm{N}$ status.

All plant-based $\mathrm{N}$ monitoring techniques share a fundamental limitation as a water quality protection practice. They can provide an indication of current crop $\mathrm{N}$ status. However, given the insensitivity of plant diagnostics to soil $\mathrm{NO}_{3}-\mathrm{N}$ availability, a sufficient tissue $\mathrm{N}$ value provides no indication of future $\mathrm{N}$ fertilization requirements and therefore cannot accurately identify fields where in-season $\mathrm{N}$ application can be reduced or delayed.

In summary, seasonal $\mathrm{N}$ uptake in commercial lettuce fields averaged $145 \mathrm{~kg} \cdot \mathrm{ha}^{-1}$ with uptake over the last half of the growing season averaging $\approx 4 \mathrm{~kg} \mathrm{~N} / \mathrm{ha} / \mathrm{d}$. Current commercial $\mathrm{N}$ fertilization rates can be reduced substantially with no reduction of crop yield. PSNT was a reliable technique on which to base $\mathrm{N}$ fertilization. Leaf $\mathrm{N}$ and midrib $\mathrm{NO}_{3}-\mathrm{N}$ monitoring were of limited value in guiding in-season $\mathrm{N}$ management.

\section{Literature Cited}

Allen, J.C. 1976. A modified sine wave method for calculating degree-days. Environ. Entomol. 5:388-396.

Bates, T.E. 1971. Factors affecting critical nutrient concentrations in plants and their evaluation: A review. Soil Sci. 112:116-130.

Breschini, S.J. and T.K. Hartz. 2002. Presidedress soil nitrate testing reduces nitrogen fertilizer use and nitrate leaching hazard in lettuce production. HortScience 37:1061-1064.
Fox, R.H., G.W. Roth, K.V. Iversen, and W.P. Piekielek. 1989. Soil and tissue nitrate tests compared for predicting soil nitrogen availability to corn. Agron. J. 81:971-974.

Gardner, B.R. and W.D. Pew. 1972. Response of fall grown head lettuce to nitrogen fertilization. Univ. of Arizona Agr. Expt. Sta. Tech. Bul. 199.

Gardner, B.R. and W.D. Pew. 1974. Response of spring grown head lettuce to nitrogen fertilization. Univ. of Arizona Agr. Expt. Sta. Tech. Bul. 210.

Gardner, B.R. and W.D. Pew. 1979. Comparison of various nitrogen sources for the fertilization of winter-grown head lettuce. J. Amer. Soc. Hort. Sci. 104:534-536.

Greenwood, D.J., F. Gastal, G. Lemaire, A. Draycott, P. Millard, and J.J. Neeteson. 1991. Growth rate and $\% \mathrm{~N}$ of field grown crops: Theory and experiments. Ann. Bot. (Lond.) 67:181-190.

Greenwood, D.J., K. Kubo, I.G. Burns, and A. Draycott. 1989. Apparent recovery of fertilizer N by vegetable crops. Soil Sci. Plant Nutr. 35:367-381.

Hartz, T.K., W.E. Bendixen, and L. Wierdsma 2000. The value of pre-sidedress soil nitrate testing as a nitrogen management tool in irrigated vegetable production. HortScience 35: 651-656.

Hartz, T.K., P.R. Johnstone, E. Williams, and R.F. Smith. 2007. Establishing lettuce leaf nutrient optimum ranges through DRIS analysis. HortScience 42:143-146.

Heckman, J.R., W.T. Hlubik, D.J. Prostak, and J.W. Paterson. 1995. Pre-sidedress soil nitrate test for sweet corn. HortScience 30: 1033-1036.

Heckman, J.R., T. Morris, J.T. Sims, J.B. Sieczka, U. Krogmann, P. Nitzsche, and R. Ashley. 2002. Pre-sidedress soil nitrate test is effective for fall cabbage. HortScience 37: 113-117.

Hoque, M.M., H. Ajwa, and M. Othman. 2010. Yield and postharvest quality of lettuce in response to nitrogen, phosphorus and potassium fertilizers. HortScience 45:1539-1544.

Jackson, L.E. 1995. Root architecture in cultivated and wild lettuce (Lactuca spp.). Plant Cell Environ. 18:885-894.
Jackson, L.E., L.J. Stivers, B.T. Warden, and K.K. Tanji. 1994. Crop nitrogen utilization and soil nitrate loss in a lettuce field. Fert. Res. 37:93105.

Jones, J.B., B. Wolf, and H.A. Mills. 1991. Plant analysis handbook. Macro-Micro Publishing, Athens, GA.

Lorenz, O.A. and K.B. Tyler. 1983. Plant tissue analysis of vegetable crops, p. 24-29. In: Reisenaur, H.M. (ed.). Soil and plant tissue testing in California. California Coop. Ext. Bul. 1879.

Maier, N.A., A.P. Dahlenberg, and T.K. Twigden. 1990. Assessment of the nitrogen status of onions (Allium cepa L.) cv. Cream Gold by plant analysis. Aust. J. Exp. Agr. 30:853-859.

MacKerron, D.K.L., M.W. Young, and H.V. Davies. 1995. A critical assessment of the value of petiole sap analysis in optimizing the nitrogen nutrition of the potato crop. Plant Soil 172:247-260.

Maynard, D.N., A.V. Barker, P.L. Minotti, and N.H. Peck. 1976. Nitrate accumulation in vegetables. Adv. Agron. 28:71-117.

Monterey County Agricultural Commissioner. 2000, 2010. Crop report. <http://www.ag.co.monterey. ca.us/resources/category/crop-reports $>$.

Pruitt, W.D., E. Fereres, and R.L. Snyder. 1987. Reference evapotranspiration $\left(\mathrm{ET}_{\mathrm{o}}\right)$ for California. Univ. of Calif. Coop. Ext. Bul. 1922.

Tei, F., P. Benincasa, and M. Guiducci. 2003. Critical nitrogen in lettuce. Acta Hort. 627: 187-194.

Waugh, D.L., R.B. Cate, and L.A. Nelson. 1973. Discontinuous models for rapid correlation, interpretation and utilization of soil analysis and fertilizer response data. Tech. Bull. 7. Int. Soil Fertility Evaluation and Improvement Program. North Carolina State Univ., Raleigh, NC.

Welch, N.C., K.B. Tyler, and D. Ririe. 1979. Nitrogen stabilization in the Pajaro Valley in lettuce, celery and strawberries. Calif. Agr. 33:12-13.

Westerveld, S.M., A.W. McKeown, C.D. ScottDupree, and M.R. McDonald. 2003. How well do critical nitrogen concentrations work for cabbage, carrot and onion crops? HortScience $38: 1122-1128.3$ 